\title{
Ozone over the Western Mediterranean Sea - results from two years of shipborne measurements
}

\author{
K. Velchev, F. Cavalli, J. Hjorth, E. Marmer, E. Vignati, F. Dentener, and F. Raes \\ European Commission, Joint Research Centre, Institute for Environment and Sustainability, Via E. Fermi, \\ 21020 Ispra (VA), Italy
}

Received: 11 December 2009 - Published in Atmos. Chem. Phys. Discuss.: 3 March 2010

Revised: 19 November 2010 - Accepted: 17 December 2010 - Published: 24 January 2011

\begin{abstract}
Ozone, along with other air pollutants, has been measured for two years from a monitoring station placed on a cruise ship that follows a regular track in the Western Mediterranean between April and October. Conditions favouring high ozone levels have been studied by analysis of weather maps and back trajectories. This analysis was focused on a transect over the open sea in the South Western Mediterranean between Tunis and Palma de Mallorca. High ozone levels were found in situations with an anticyclonic circulation over the Western Mediterranean when subsidence brings air masses down from altitudes between 1000 and $3500 \mathrm{~m}$ a.s.l. Analysis of composite meteorological maps suggests a relevant contribution of breeze circulation to subsidence during events with high surface ozone concentrations; this points to an important contribution from local ozone formation. A detailed back trajectory analysis of the origin of air masses with high ozone concentrations was carried out for two "hot spots" for ozone pollution, in the Gulf of Genoa and between Naples and Palermo, respectively. The main cause of high ozone levels in the Gulf of Genoa was found to be outflow from the Po Valley and the Genoa area while such episodes along the Naples-Palermo transect were most often associated with trajectories from the Rome or Naples areas. Analysis of the relationship between measured concentrations of Black Carbon and ozone allowed to evaluate the degree of photochemical "ageing" of the air masses encountered along the route of the cruise ship.
\end{abstract}

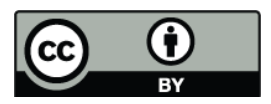

Correspondence to: J. Hjorth

(jens.hjorth@jrc.ec.europa.eu)

\section{Introduction}

Ozone $\left(\mathrm{O}_{3}\right)$, along with water vapour $\left(\mathrm{H}_{2} \mathrm{O}\right)$, carbon dioxide $\left(\mathrm{CO}_{2}\right)$, methane $\left(\mathrm{CH}_{4}\right)$ and nitrous oxide $\left(\mathrm{N}_{2} \mathrm{O}\right)$, is a greenhouse gas that changes the radiative balance of the Earth's surface and contributes to climate change; it ranks as the fourth most important contributor to global warming (IPCC, 2007). Moreover, ozone is a strong oxidant with harmful effects on plants, animals and humans. Although emissions of ozone precursor gases decreased substantially in Europe, both annual and eight-hourly average ground-level ozone concentrations relevant to EU limit values did not show a decrease (EEA, 2007).

Data from monitoring stations as well as results of measurement campaigns show that ozone concentrations in the Mediterranean Basin appear to be relatively high: Lelieveld et al. (2002) found summer $\mathrm{O}_{3}$ concentrations over the Mediterranean a factor of 2.5-3 higher than in the hemispheric background troposphere in the boundary layer and up to $4 \mathrm{~km}$ altitude. Rural stations in continental Greece, Italy and eastern Spain report summer average ozone values of about $60-70 \mathrm{ppbv}$, significantly higher than values in Northern and Western Europe (Kalabokas and Repapis, 2004; Paoletti, 2006; Millan et al., 2000). Observations at the islands of Gozo (Malta), Crete (Greece) and Cyprus indicate also high ozone values; monthly averages of ozone mixing ratios at Gozo are among the highest found worldwide for low altitude stations, with maximum values on average of $56 \mathrm{ppbv}$ in spring and minimum average values for the winter months of $44 \mathrm{ppbv}$ (Nolle et al., 2002), a value that is approximately twice as high as on the European continent. Thus, available nowadays ozone measurements suggest that the entire Mediterranean region is characterised not only by photochemical episodes in urban areas, but also by high background ozone concentrations. Results from a 3-D chemistry transport model also suggest that ozone concentrations

Published by Copernicus Publications on behalf of the European Geosciences Union. 
over the Mediterranean Sea are higher than for the rest of Europe (e.g. Johnson et al., 2001). A major question is to what extend this background ozone is related to sources within the Mediterranean Basin and how much it results from long range transport of ozone and precursors emitted outside the Basin.

High ozone values are typical not only for ground level measurements in the Mediterranean, but in the entire boundary layer. Vertical ozone profiles provided by 77 MOZAIC flights revealed significantly enhanced (20-40\%) ozone levels in the $1000 \mathrm{hPa}-900 \mathrm{hPa}$ layer of the Eastern Mediterranean with respect to Central Europe (Kalabokas et al., 2007). In the western part, along the Spanish coast in summer, the presence of stacked ozone layers reaching $2-3 \mathrm{~km}$ in height and extending more than $300 \mathrm{~km}$ out to sea have been reported by Millan et al. (1997, 2000, 2005).

The ozone behaviour and distribution in the Mediterranean region are closely related to its unique geographical characteristics and specific weather conditions. During the summer period, the Mediterranean area is directly under the descending branch of the Hadley circulation, caused by deep convection in the tropics (Lelieveld, 2009). The region incorporates the world's largest inland sea, which is surrounded by relatively high mountain ridges on almost every side; its climate is in general warm and dry (Bolle, 2003). The Mediterranean summers, connected with high pressure situations leading to subsidence, stability, clear sky and high solar radiation intensity, enhance photochemical processes and emissions of biogenic volatile organic compounds to the atmosphere (Millan et al., 2002). In the mid-troposphere also transport of pollutants across the Atlantic is of relevance (Lelieveld et al., 2002).

However, the physical and chemical processes leading to $\mathrm{O}_{3}$ formation appear to vary greatly within the Mediterranean basins: In the Western Mediterranean, the complex layout of the coasts and surrounding mountains favours the development of combined sea breeze - upslope winds and the evolution of return flows with several layers of pollutants and subsidence over the coast and the sea during daytime in summer. At night, land breezes can store polluted air masses above the maritime boundary layer and thus build reservoirs of aged polluted air that may return onshore on the following day (Gangoiti et al., 2001; Ancellet and Ravetta, 2005). A recent modeling study concerning the northwestern Mediterranean basin finds that local recirculation is of key importance for the surface concentration of ozone (Jiménez, 2006). Similar processes have been documented for the Central Mediterranean (Georgiadis et al., 1994) and for the Tunisian Coast (Bouchlaghem et al., 2008).

The sea-breeze recirculation is common in many locations, so that air can remain within a region for a prolonged period, and thus ozone formation due to local and regional sources is expected to be more important than in Central and Northern Europe (Beck et al., 1999). However, based on observational and modelling data, also long range transport of European air toward the Mediterranean Basin has been found to be a main cause of elevated ozone concentrations in the Western Mediterranean area (Lelieveld et al., 2002).

The Eastern Mediterranean in summer is affected by semipersistent strong northerly winds (Etesian winds), the development of recirculations is largely inhibited and high levels of lower tropospheric ozone are associated with transport of polluted air from the Balkans and Eastern Europe (Ziomas et al., 1998; Kalabokas et al., 2007, 2008).

Background ozone data for the Mediterranean basin are provided by the EMEP stations on a regular basis. However, only a few of these stations are located close to the sea and they do not cover the whole area. Additionally, various measurement campaigns have been conducted, particularly at the Spanish East coast, in Southern France and at the Aegean Sea. Some campaigns included ozonesonde and/or flight data, and shipborne observations besides ground based measurements, however they do not provide continuous observations over the open sea. Such measurements are particularly needed to assess the regional climate effects of ozone.

In an attempt to fill in the gap of observations in the Mediterranean basin and to gain more insight into the atmospheric dynamical and chemical mechanisms leading to high surface ozone levels, the Joint Research Centre of the European Commission (JRC, EC) has started regular ship borne measurements over the Mediterranean Sea. In 2005 a collaboration has been established between JRC-EC and the Italian cruise line Costa Crociere. In this context a monitoring station for ozone and black carbon aerosols (BC) was installed on board of the cruise ship Costa Fortuna, which had a regular weekly route in the Western Mediterranean during spring, summer and autumn for two years (2006 and 2007) and in the Eastern Mediterranean in winter 2006.

These measurements are planned to be continued for a longer period in order to contribute to capture trends in pollution levels. Such trends will depend on changes in emissions related to economic and technological development as well as new regulations (e.g. regarding shipping). They may also be influenced by climatic changes: it is expected that the Mediterranean climate will become increasingly warm and dry in the coming decades. Some model simulations also suggest that there will be less Mediterranean cyclones and that wind speeds on average will be reduced in this area (IPCC, 2007).

The main purpose of this paper is to present the ozone data collected during 2006-2007 on board of Costa Fortuna and to characterize the specific meteorological conditions leading to high ozone levels. The analysis, that relates ozone concentrations to synoptical situations and calculated backtrajectories, contributes to understanding the causes of ozone pollution in the area. A good understanding of the links between meteorology and ozone levels is needed to evaluate the likely effects of climatic changes on ozone levels in this area. Ozone and black carbon observations from the Costa Crociere cruise ship in the Eastern and Western 
Mediterranean have been used to verify ship emission inventories in a recent publication (Marmer et al., 2009). In the present paper we will focus on the ozone observations in the Western Mediterranean where we have the most comprehensive set of measurements available. BC measurements will here only be discussed qualitatively in relation to correlations between $\mathrm{BC}$ and ozone.

\section{Methods}

\subsection{Set-up of on-board monitoring station}

The automatic monitoring station, installed on board of Costa Fortuna, contained the following measurement equipment:

- UV Photometric Ozone Analyzer (Model C49 Thermo Electron Instruments Inc., USA),

- Aerosol Black Carbon Analyzer (Aethalometer, AE 21, 2 wavelengths, Magee Scientific, USA),

- Optical Aerosol Spectrometer (GRIMM Model 1.109, GRIMM Aerosol Technik GmbH, Germany). Data from this instrument are only available for a minor part of the measurement period.

The raw data are averaged over a $10 \mathrm{~min}$ interval and stored in a computer.

The inlet to the ozone analyzer and the Aethalometer had a cut-off at $1 \mu \mathrm{m}$ particle diameter while the inlet to the optical particle sizer had a cut-off at $10 \mu \mathrm{m}$ by homemade inertial impactors. Before entering the ozone analyzer the air passed through a $5 \mu \mathrm{m}$ PTFE Millipore membrane filter in order to remove particles. The measurement procedure complies with the recommendations in the EMEP manual (EMEP, 1996).

The ozone analyzer uses a dual cell measurement system, where ozone has been removed by a scrubber from the air going into one of them; this allows to eliminate potential interferences. The stated precision is $1 \mathrm{ppbv}$, the observed zero-drift between calibrations was $\leq 1 \mathrm{ppbv}$, the span-drift was between 0 and 3\%. Calibrations were performed by comparison to a portable primary standard (Thermo Electron 49C PS).

Information about the ships position, speed and sailing direction were received together with meteorological parameters (wind speed and direction, temperature, humidity) every 15 min.

\subsection{Selection of location for monitoring station on the ship}

The ideal location for the installation of devices measuring various gas concentrations and especially aerosol particles appears to be the frontal part, at the prow of the ship at Deck 4 (16 ma.s.l., see Fig. 1). However, as this part of the ship was unavailable for long term measurements, an

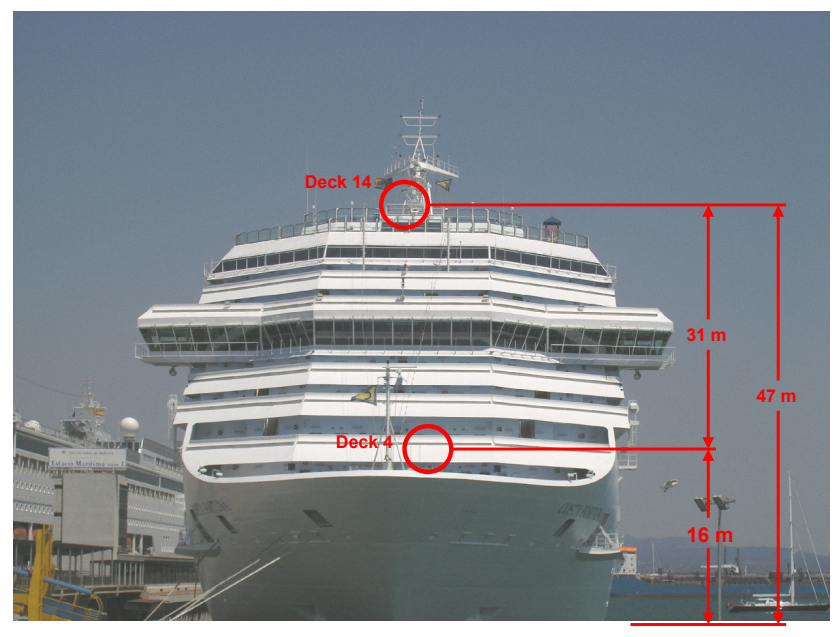

Fig. 1. Frontal view of Costa Fortuna with the locations for the instrumental set-up.

alternative location at the front of the top deck (Deck 14, $47 \mathrm{~m}$ a.s.1.) was chosen. Comparative measurements at the two locations have been carried out using two identical racks equipped with the ozone analyser, Grimm optical aerosol analyser, pumps and flow meters. The two racks were operating for $24 \mathrm{~h}$ at Deck 4, and then one was moved to Deck 14. Simultaneous measurements have been performed for one week in July 2005 during a regular ship cruise along the track Savona-Naples-Palermo-Tunis-Palma de MallorcaBarcelona-Marseille-Savona.

The difference between the ozone values measured at Deck 4 and Deck 14 are small (see Fig. 2); significant differences for ozone between Deck 14 and Deck 4 have been observed only in Palma de Mallorca (the ellipse on the top panel) due to overheating of the Deck 4 device. Also the differences between the aerosol volumes measured at the two locations were within the error interval for this type of measurements, apart from some occasions in harbours with strong local emission sources and during a fog episode in the Gulf of Lion, where the height difference between the two stations is likely to be important.

Further in our analysis we will use the data obtained at Deck 14 during the period April-October in 2006 and 2007.

\subsection{Filtering of data}

The observations used for the analysis of ozone concentrations over the open sea, discussed in the following, have been filtered in the following way:

- measurements done in harbours and their nearest surroundings (the last two hours before arrival and the first two hours after departure) have been excluded from the general analysis and are treated separately. 


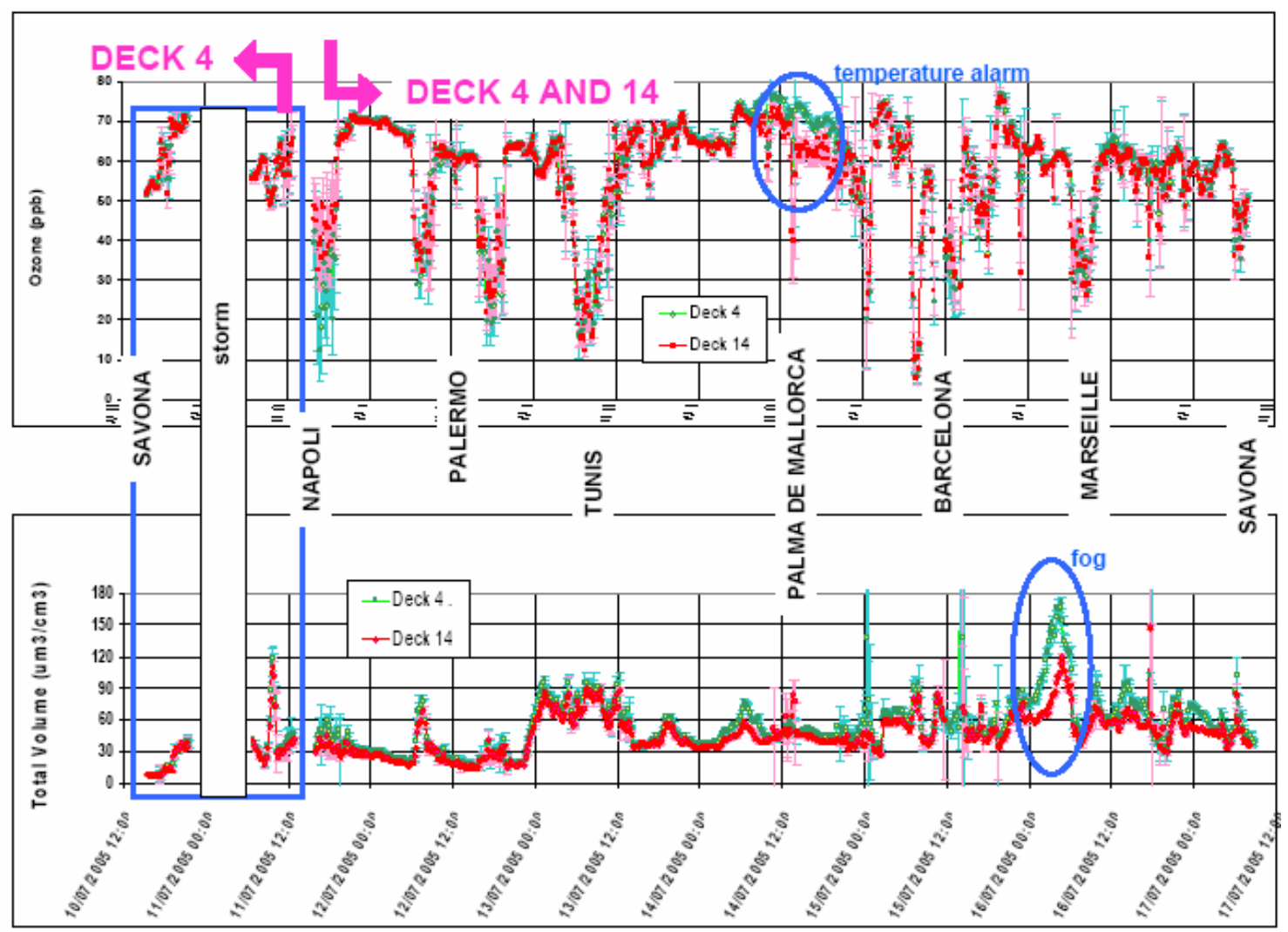

Fig. 2. Simultaneous measurements of ozone (top) and aerosol (bottom) during 10-17 July 2005 at Deck 4 (green) and Deck 14 (red), the blue square marks the period with devices operating side by side on Deck 4, ellipses mark highest differences. See discussion in Sect. 2.2 .

- measurements where a comparison of wind speed and direction with the speed and course of the ship showed that smoke from the stack of the ship might reach the monitoring station (ship speed smaller than wind speed, difference between wind direction and course of ship less than $30^{\circ}$ ) have been excluded as well.

- measurements where high BC values and ozone values close to zero show a strong influence of nearby emissions from combustion sources have been excluded.

The Aethalometer measures optical absorption of aerosols at two wavelengths: 0.37 and $0.88 \mu \mathrm{m}$. Generally BC is calculated from the absorption measured at $0.88 \mu \mathrm{m}$ as $\mathrm{BC}$ is found to typically account for most absorption of light at this wavelength. Dust, due to the content of hematite, tend to absorb strongest at wavelengths below $0.6 \mu \mathrm{m}$ (Soholik and Toon, 1999), however non-negligible interferences have been observed also at $0.88 \mu \mathrm{m}$. A study of aerosol optical absorption during dust episodes (F. Cavalli, personal communication, 2010) has shown, that the ratio between the absorption at 0.37 and $0.88 \mu \mathrm{m}$ under these conditions increases to reach values above 1.4. Based on this result the Aethalometer $\mathrm{BC}$ measurements were examined and those that showed evidence of interference by dust were excluded.

\section{Results and discussion}

\subsection{Overview of the data - Western Mediterranean}

The summer route of Costa Fortuna in the Mediterranean Sea is shown on Fig. 3. In most cases the ship arrives in a port in the morning (07:00-09:00 LT) and leaves in the late afternoon/early evening (17:00-19:00 LT); thus the ship sails mainly during the night. The only exceptions are the two longest legs: Savona-Naples (departure 17:00 LT, arrival 13:00 LT next day) and Tunis-Palma de Mallorca (departure 13:00 LT, arrival 14:00 LT next day). Local time (LT) is for all data shown UT plus two hours.

The measurements of ozone and $\mathrm{BC}$ performed during the summer periods (April-October) of 2006 and 2007 are shown in Fig. 4. The figure shows all measurements, including harbours; in the harbours a strong anticorrelation between $\mathrm{BC}$ and ozone is found, as expected, because the high $\mathrm{BC}$ levels in harbours are caused by local combustion sources that also emit NO that destroys ozone by a fast "titration" reaction. Seasonally averaged measurements, excluding harbours, are shown in Fig. 5, plotted on a grid scale of $1^{\circ} \times 1^{\circ}$.

The patterns of measurements show a remarkable similarity between the average weekly concentration profiles 


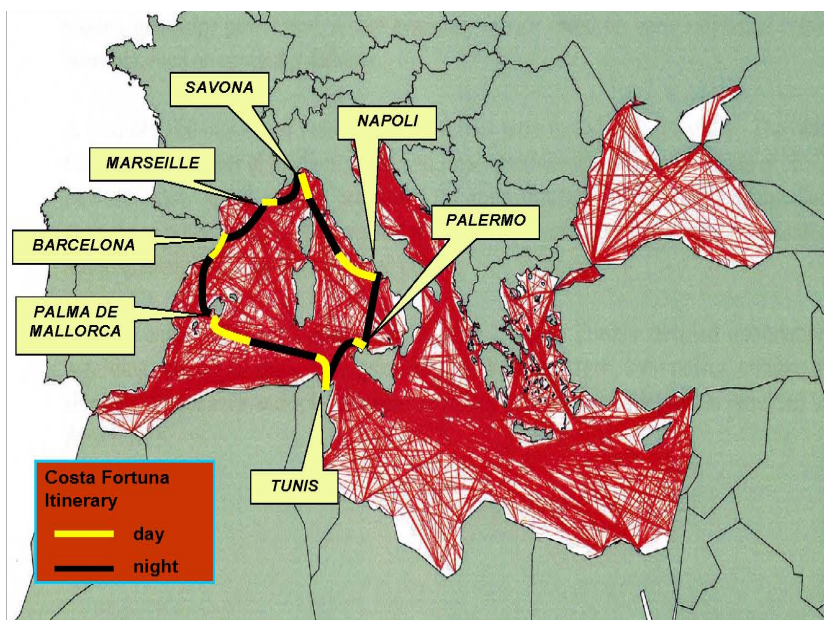

Fig. 3. The route of Cost Fortuna during the period AprilOctober 2006 and 2007. The red lines indicate ship trajectories in the Mediterranean (adapted from the Lloyd Register Report 99/EE/7044, Lavander, 2001). "Day" is 07:00 a.m. to 07:00 p.m. LT, "Night" is 07:00 p.m. to 07:00 a.m. LT.

observed during the two years. This similarity is not only caused by the impact of harbours, causing ozone minima at these points both years; there is also a very similar behaviour of the measurements over the sea for the two years. This may be explained by the fact that high (and to some extent also low) ozone concentrations are found in situations with a characteristic type of air circulation, as discussed in the following, and thus tend to show a similar geographical distribution of the ozone concentration levels. Also the impact of "titration" by NO from local sources seems to play a role, most evidently in the concentration "dip" found between Savona and Naples, observed in the vicinity of the Rome area.

Although the measurements show similar variations along the track both years, with the highest values in the same areas, there is a difference between the absolute concentration level in the summer of 2006 and that of 2007 , the latter being significantly lower. For example, over the long leg between Tunis and La Palma, the average ozone in June-July-August 2006 was $51 \mathrm{ppbv}$ while it was $46 \mathrm{ppbv}$ for the same period in 2007; looking at July only, the difference between the two years was as large as $55 \mathrm{ppbv}$ compared to $41 \mathrm{ppbv}$.

Statistical information about the ozone concentrations measured along each of the legs of the cruise during the summer period (June, July and August) is shown in Table 1. The highest values are found along the leg NaplesPalermo, followed by Marseille-Savona and Palermo-Tunis. The highest peak values ( $90 \%$ percentile) were also found between Naples and Palermo, followed by Marseille-Savona and Savona-Naples. The largest difference, $31.0 \mathrm{ppbv}$, between the highest and the lowest values (90\% vs. $10 \%$ percentile) were found on the leg Marseille-Savona, while the smallest difference, $21.4 \mathrm{ppbv}$, was found along the leg
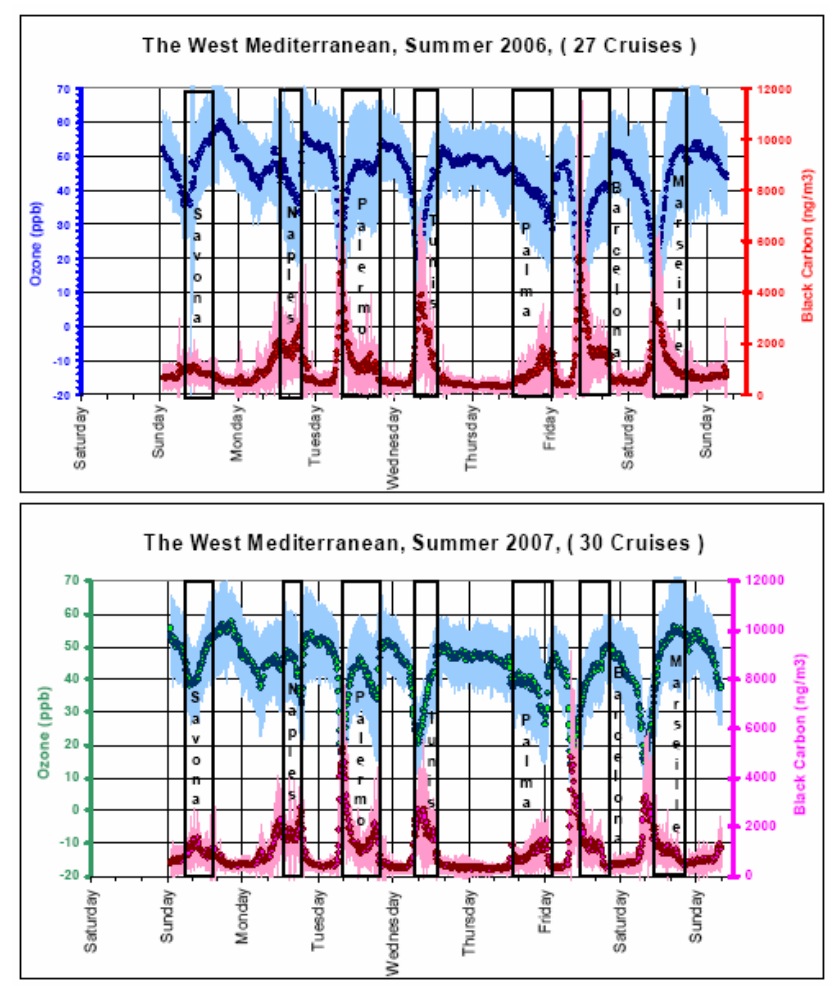

Fig. 4. Ozone and black carbon concentrations in the West Mediterranean as measured along the cruise track. The figure shows average values with standard deviation for the periods April-October 2006 and 2007. The black columns show the periods where Costa Fortuna is at berth in ports.

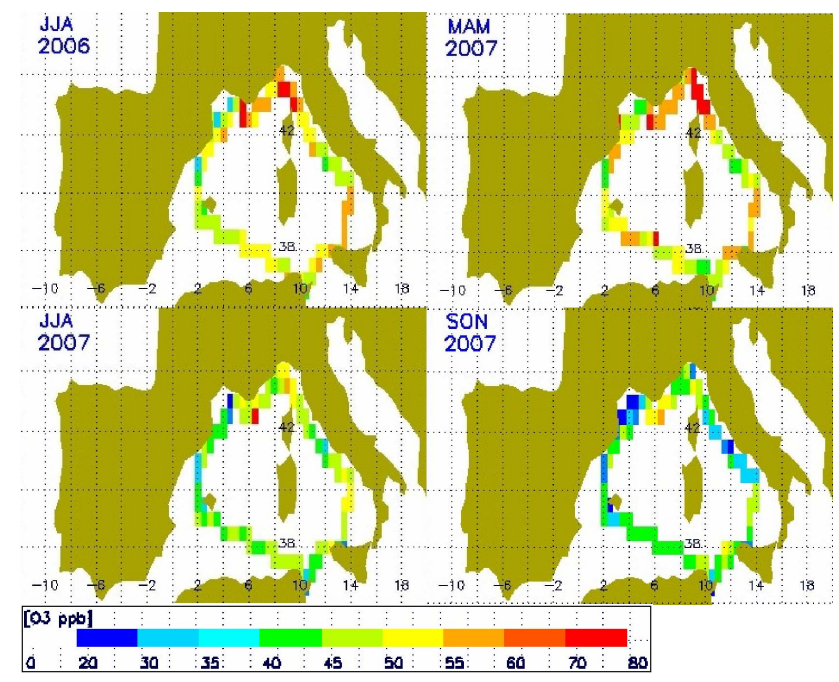

Fig. 5. Plots of averaged measured concentrations of ozone during the summer (June, July August) for the year 2006 and summer, spring (March, April May) and autumn (September, October, November) for 2007. The data have been filtered as described above. 
Table 1. Statistics on ozone concentrations (in ppbv) for each cruise leg for the periods June, July, August 2006 and 2007.

\begin{tabular}{lrrrrrrrr}
\hline & $\begin{array}{r}\text { Savona- } \\
\text { Naples }\end{array}$ & $\begin{array}{r}\text { Naples- } \\
\text { Palermo }\end{array}$ & $\begin{array}{r}\text { Palermo- } \\
\text { Tunis }\end{array}$ & $\begin{array}{r}\text { Tunis- } \\
\text { Palma de Mallorca }\end{array}$ & $\begin{array}{r}\text { Palma de Mallorca- } \\
\text { Barcelona }\end{array}$ & $\begin{array}{r}\text { Barcelona- } \\
\text { Marseille }\end{array}$ & $\begin{array}{r}\text { Marseille- } \\
\text { Savona }\end{array}$ & All \\
\hline Mean & 51.0 & 57.1 & 52.8 & 50.4 & 48.3 & 46.9 & 53.5 & 50.1 \\
Standard deviation & 9.9 & 9.5 & 9.2 & 8.9 & 9.9 & 12.0 & 13.7 & 10.0 \\
Median & 49.23 & 55.8 & 54.4 & 49.9 & 49.7 & 48.1 & 53.7 & 49.5 \\
90\% percentile & 64.4 & 68.6 & 63.1 & 61.7 & 58.6 & 59.6 & 67.0 & 62.5 \\
\hline 10\% percentile & 39.6 & 46.4 & 39.3 & 40.2 & 36.2 & 32.2 & 36.0 & 38.5 \\
\hline
\end{tabular}

Tunis-Palma. Thus, as expected, the highest variability is found on a leg along the coast while the lowest variability is found on an open sea leg.

\subsection{Diurnal variations}

The fact that most of the measurements over the open sea are performed during night time must be taken into account when evaluating the data. Ground level ozone shows a diurnal variation caused by the balance between transport, sinks and the photochemical sources, usually with a maximum during the daytime. However, over the open sea both sources and sinks are likely to be relatively small. Deposition of ozone on water is slow and also the photochemical formation of ozone is slow due to the low precursor concentrations, so diurnal variations are expected to be small.

An estimate of the amplitude of the diurnal cycle of ozone over the sea can be made by looking at observations made on islands in the area. The observations made at two EMEP stations during 1999-2002 located at the islands of Malta and Crete have been analysed, the data have been obtained from the EMEP website (EMEP, 2009).

The most notable feature of the monthly averaged daily ozone cycle at these stations is the low amplitude, not exceeding 7-8\% with respect to the means of the diurnal values. Long term measurements at Gozo, Malta confirm this diurnal behaviour (Nolle et al., 2002). For the Eastern Mediterranean, at Finokalia, Crete, Kouvarakis et al. (2002) report an amplitude of $8 \%$ for the diurnal ozone variation and note that this is in agreement with diurnal amplitudes observed in remote marine locations.

Based on the ozone data for the islands we assume that the diurnal variation of ozone over open sea should be small (typically not more than $\pm 2.5 \mathrm{ppbv}$ ), implying that our onboard night time ozone measurements over the open sea could be treated as representative also for the day-time.

This diurnal behaviour is not typical for land stations, where the ozone amplitude is strongly related not only to the solar radiation, but also to the topographic location of the observing station, the atmospheric circulations, local emissions and the higher ozone deposition velocities over land (Millan et al., 2000).
The concentrations measured in harbours show a completely different behaviour, as they are subject to local sources and coastal meteorology. The observations of ozone, $\mathrm{BC}$ and meteorological parameters at Costa Fortuna while at berth in harbours showed in many cases the influence of seabreeze circulation: Maximum $\mathrm{BC}$ values and minimum ozone values are found during the windless conditions in the early morning where local emissions accumulate and give maximum $\mathrm{BC}$ values and minimum ozone values (due to its reaction with NO); after the onset of the breeze circulation ozone concentrations start to increase to reach maximum values in the afternoon.

In Chapter 4 we will focus the discussion of the data on understanding the causes of elevated ozone concentrations through characterisation of the source regions by trajectory analysis and analysis of the synoptical situations and their relation to ozone levels in this area.

\section{Data analysis}

\subsection{Relation between ozone levels and synoptic situation}

We will focus here on ozone data obtained during the longest leg over the sea, from Tunis to Palma de Mallorca, about $800 \mathrm{~km}$, which the vessel takes for $24 \mathrm{~h}$. For the spring summer period of 2006 and 200742 study cases of $24 \mathrm{~h}$ continuous ozone measurements are available from the measurements performed on Costa Fortuna.

For the analysis all cases have been classified into 3 groups (Table 2):

- The first group (8 cases) is characterized by high ozone concentrations - around or above 60 ppbv observed for more than one hour.

- The second group includes 9 cases with relatively low ozone concentrations - below $40 \mathrm{ppbv}$, observed for more than one hour.

- The third group includes the remaining 25 cases with intermediate mean ozone values of 40-60 ppbv. 
Table 2. Grouping of periods according to measured ozone concentrations (see text).

\begin{tabular}{lll}
\hline & 2006 & 2007 \\
\hline $\begin{array}{l}\text { Group 1 } \\
\begin{array}{l}\text { High ozone } \\
\text { concentrations }\end{array}\end{array}$ & $\begin{array}{l}\text { 7-8 June, 21-22 June, 12-13 July, } \\
\text { 6-7 September }\end{array}$ & 25-26 April, 9-10 May, 13-14 June, 18 July \\
\hline $\begin{array}{l}\text { Group 2 } \\
\text { Low ozone } \\
\text { concentrations }\end{array}$ & $\begin{array}{l}\text { 28-29 June, 05-06 July, 27-28 September, } \\
\text { 4-5 October, 18-19 October }\end{array}$ & 2-3 May, 20-21, 27-28 June, 19 July \\
\hline $\begin{array}{l}\text { Group 3 } \\
\text { Intermediate ozone } \\
\text { concentrations }\end{array}$ & $\begin{array}{l}\text { 26-27 April, 3-4, 10-11, 24-25 May-1 June, 14-15 June, 5-6, 19-20, 26-27 July, } \\
\text { 2-3, 9-10, 16-17, 23-24, 30-31 August, } \\
\text { 13-14, 20-21 September, 11-12 October }\end{array}$ & \\
\hline
\end{tabular}

$60 \mathrm{ppbv}$ is the 8-hours EU air quality standard while $40 \mathrm{ppbv}$ corresponds to reported values for clean marine air (Anderson et al, 1993) and is regarded to be representative for clean marine air levels of ozone in the Eastern Mediterranean (Kourtidis et al., 2002).

For each group we have examined the synoptic situation over the Mediterranean trying to understand the influence it might have on the observed open sea ozone concentrations. The weather charts analysis suggested complex synoptic patterns for most of the study cases. However, some similarities have been identified for the cases inside a given group.

The High Ozone group (named "High" hereafter) is characterized by an anticyclone situated above the Mediterranean Sea, typical for spring or early summer. The common synoptic feature for the cases in this group is the anticyclonic circulation with isobars following to a great extent the curvature of the sea coast. This circulation was present at the moment of the vessel passage along the leg, or the circulation was well evident some hours before the ship's passage. The individual features of the single cases are related to the type of the anticyclone: a synoptic (large-scale) high pressure system or regional (mesoscale) anticyclonic circulation developed by local thermal factors.

The Low Ozone group (named "Low" hereafter) is strongly associated with the presence of a low pressure system (cyclone) located near the leg. The synoptic features are more complex and measured ozone concentrations seem to be dependant on the frontal position and the related wind and precipitation phenomena.

The "in between" group has not been analyzed in detail. It may well contain days with synoptic situations similar to either the "High" or the "Low" groups but where the duration of this situation has been too short to lead to extreme values.

In order to gain more insight into the atmospheric processes in the lower troposphere over the Mediterranean and their relationship to the ozone concentrations in the "High" and "Low" groups we have further analyzed composite weather maps, constructed from the NCEP/NCAR reanalysis following the procedure of Kalnay et al. (1996). These maps provide a picture of the average meteorological conditions for the two groups. It should be noted that the composite maps are obtained with a coarse resolution model $\left(2.5 \times 2.5^{\circ}\right)$, but we find that for qualitative analysis these maps are useful in identifying and describing baric centers over the Western Mediterranean.

The composite maps for the geopotential height at the surface $(1000 \mathrm{hPa})$ and at about $1500 \mathrm{~m}$ a.s.l. $(850 \mathrm{hPa})$ for the "High" and "Low" groups are shown on Fig. 6a, b, where the region around the route from Tunis to Palma de Mallorca is indicated by an ellipse. At about $1500 \mathrm{~m}$ a.s.l. the maps at synoptic scale are similar with a ridge of high pressure extending from North Africa over the Western Mediterranean Sea towards Central Europe. However, at the surface $(1000 \mathrm{hPa})$ there is a significant difference between the "Low" and the "High" maps for the region we are interested in. There is a low pressure for the "Low" ozone group. On the contrary, a high pressure ridge is noticeable for the "High" ozone group (see the ellipse on the map). This high pressure ridge appears at surface level only and is characterized by small baric gradients. This baric formation, as well as the analysis of the relative weather maps (not shown here), suggest that the pressure distribution in the "High" ozone group is due to a well developed sea breeze circulation and its interaction with the synoptic scale high pressure ridge. This shallow high pressure baric formation will hereafter be named "regional summer anticyclone".

The effect of the interaction between these baric formations could be seen on maps of the vertical velocity.

The composite maps for the vertical velocity are of particular interest, since vertical transport is associated with subsidence in the typical summer anticyclonic circulation. Widespread subsidence can enhance surface ozone by bringing higher levels of ozone down from the upper troposphere (e.g. Fishman et al., 2005). 

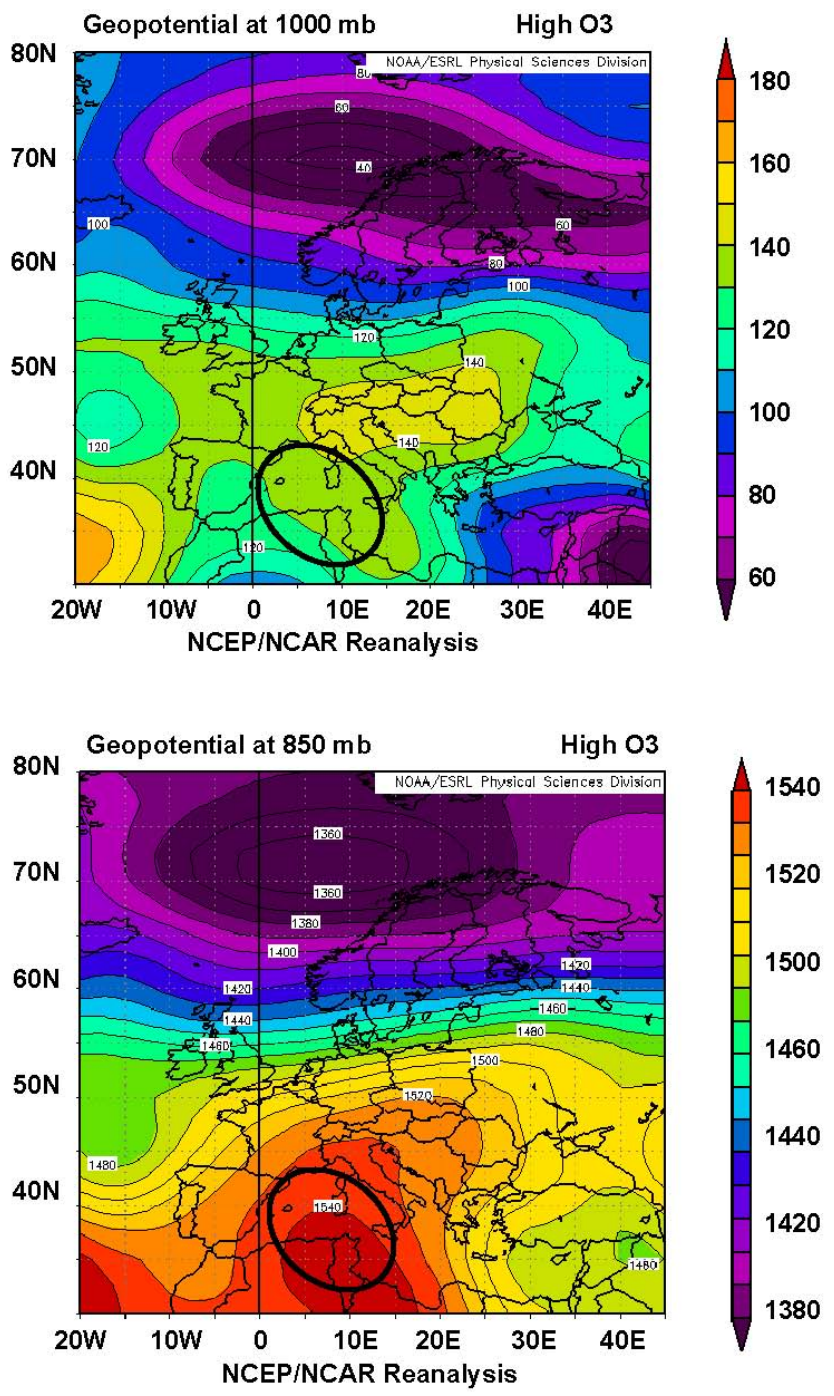

Fig. 6a. Composite maps of the geopotential height for the "High" ozone episodes at 1000 (upper) and at $850 \mathrm{hPa}$.

Composite maps of vertical velocities in a south-to-north vertical cross section near the leg of the ship (longitude $7^{\circ} \mathrm{E}$ ) are shown in Fig. 7. For the "High" group an intensive sinking can be noticed over the sea while upward motions are evident above the land. This circulation pattern has a horizontal dimension of about $700 \mathrm{~km}$ and vertical extension of about $3 \mathrm{~km}$. The maximum downward velocities are at a height of about $900 \mathrm{hPa}$, which corresponds approximately to $1000 \mathrm{~m}$ a.s.l. At the same height Kalabokas et al. (2007) report maximum ozone concentrations for the Eastern Mediterranean.

Previous studies of the summer circulation in the Western Mediterranean basin (Millan et al., 1997, 2000, 2002, 2005) bring evidence that within the general subsidence due to the Azores anticyclone, a compensatory subsidence occurs in response to the development of the sea breeze circulation
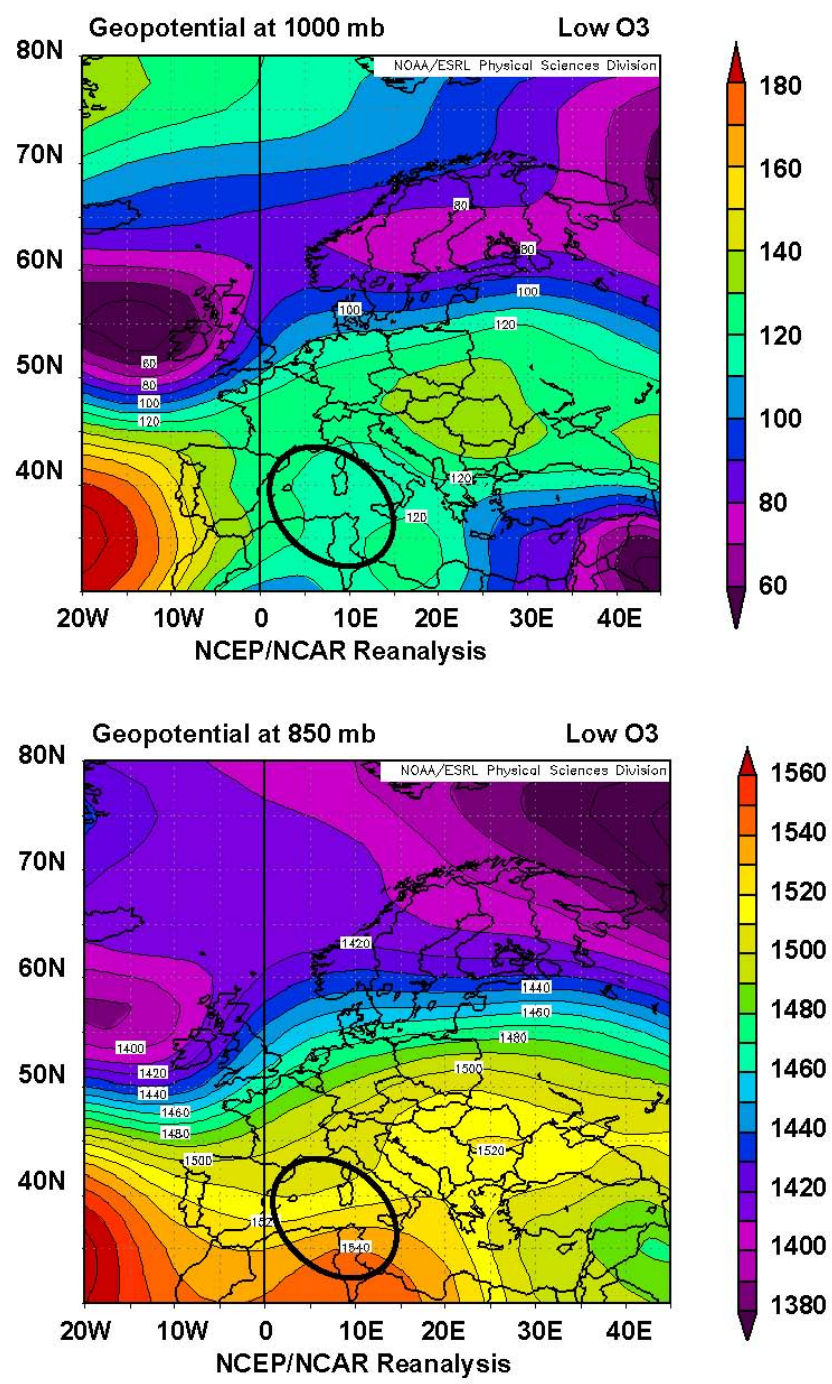

Fig. 6b. Composite maps of the geopotential height for the "Low" ozone episodes at 1000 (upper) and at $850 \mathrm{hPa}$.

and the Iberian Thermal low (a low pressure system over the Iberian peninsula typical for the summer). In an attempt to understand how these thermal circulation effects can influence the ozone levels also in the region between Tunis and Palma de Mallorca, composite weather maps of the vertical velocity in a south-to-north vertical cross section for different times of the day have been analysed.

Figure 8 shows the composite maps at two synoptic hours representative for the sea/land breeze circulation. At 18:00 UTC when the sea breeze is still well developed, strong subsidence over the sea is noticed. At 06:00 UTC a sea level convergence and respective upward motions over the open sea are visible on the map. These Figures suggest that the land/sea breeze can affect the circulation over the sea and might have impact on the intensity and the vertical extent of the subsidence. 

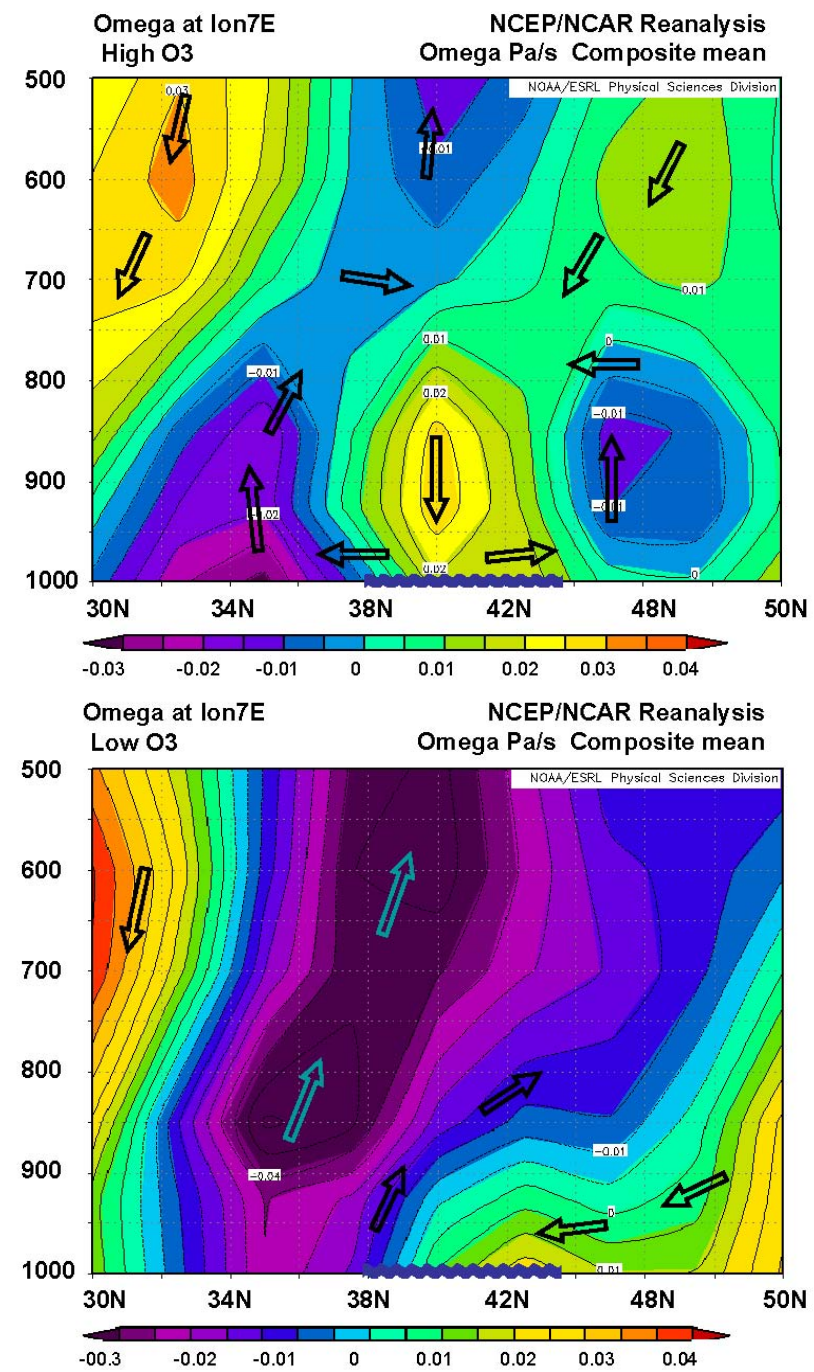

Fig. 7. Composite maps for the vertical velocity (omega) in $\mathrm{Pa} / \mathrm{s}$ - south-to-north vertical cross section at longitude of $7^{\circ} \mathrm{E}$ for the "High" and the "Low" ozone groups. The sea is marked by the blue waves; the arrows indicate the direction of the motions.

\subsection{Backward trajectories for the leg Tunis-Palma de Mallorca}

Ground level ozone in the Mediterranean Basin is controlled not only by internal formation and loss processes, but also by ozone imported into the Basin and it is influenced by changes in the background ozone concentrations. Since its photochemical lifetime is about $1-4$ weeks above the well mixed boundary layer, ozone has the potential to be transported and mixed over large scales (EMEP/CCC Report, 2005).

To investigate the relationship between ozone concentrations observed on Costa Fortuna along the track Tunis-Palma de Mallorca and the origin of the air masses arriving there, 5-day backward trajectories have been computed for the episodes with persistent high or low ozone concentrations (see Sect. 4.1).

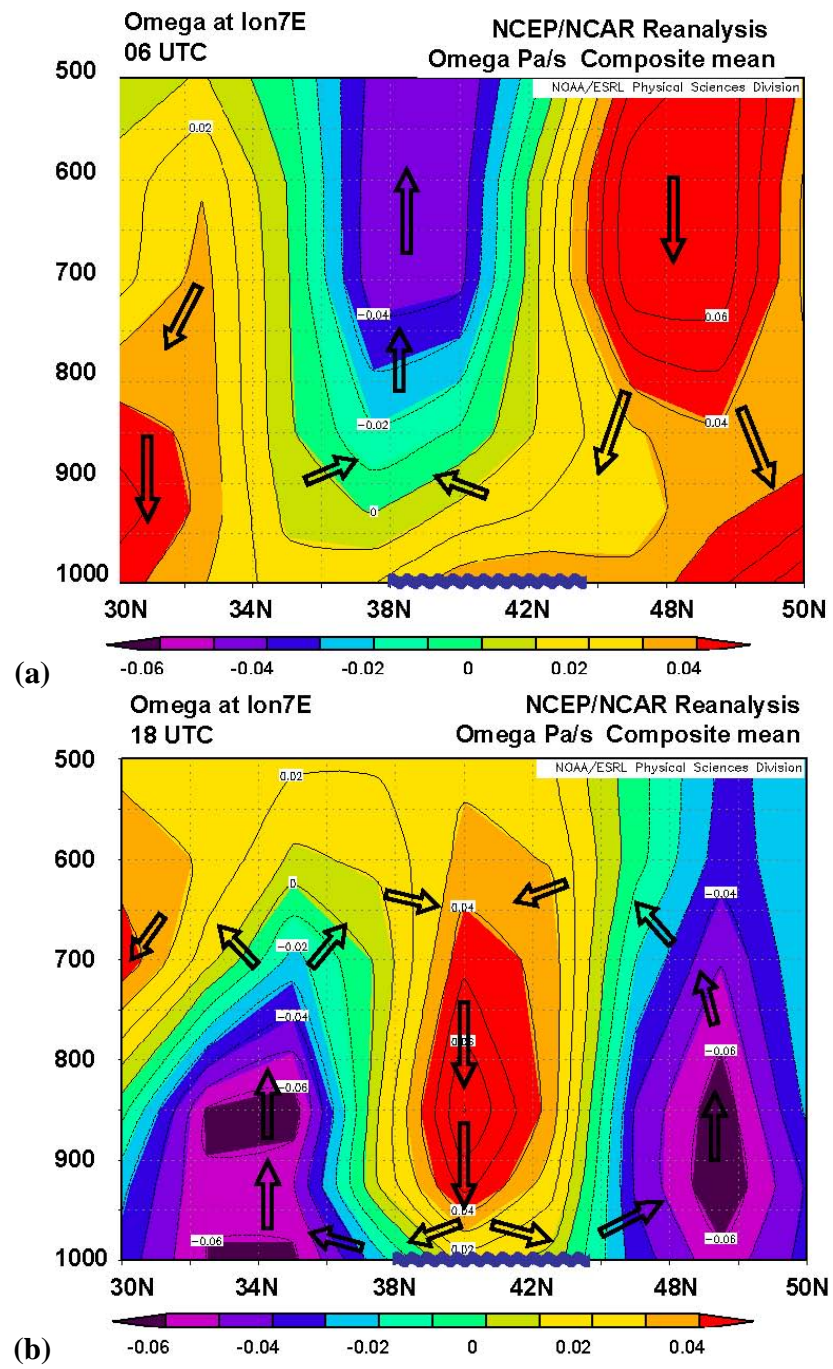

Fig. 8. Composite maps for the vertical velocity (omega) in $\mathrm{Pa} / \mathrm{s}$ - south-to-north vertical cross section at longitude of $7^{\circ} \mathrm{E}$ for the "High" ozone group: (a) 06:00 UTC (b) 18:00 UTC. The sea is marked by the blue waves; the arrows indicate the direction of the motions.

The trajectories were calculated using the BADC trajectory service (BADC, 2007) with $1.125 \times 1.125$ degree resolution ECWMF archived data (91 vertical layers). The same calculations were performed using the US NOAA Hysplit website (HYSPLIT, 2007) with GDAS meteorological data $\left(1 \times 1^{\circ}\right.$ horizontal resolution, 23 vertical layers); although minor differences between the two sets of calculations were found, the qualitative picture they provided were the same.

As an example we present here the results for two typical cases from the "High" group, (Fig. 9). The first case is for a "regional summer anticyclone" in the Western Mediterranean, induced by well developed breeze circulations. The subsidence is from about $1500 \mathrm{~m}$. For the second case the weather conditions are determined by a synoptic anticyclone with subsidence coming from an altitude of about $3000 \mathrm{~m}$. 
NOAA HYSPLIT MODEL

Backward trajectories ending at 0600 UTC 07 Sep 06 GDAS Meteorological Data

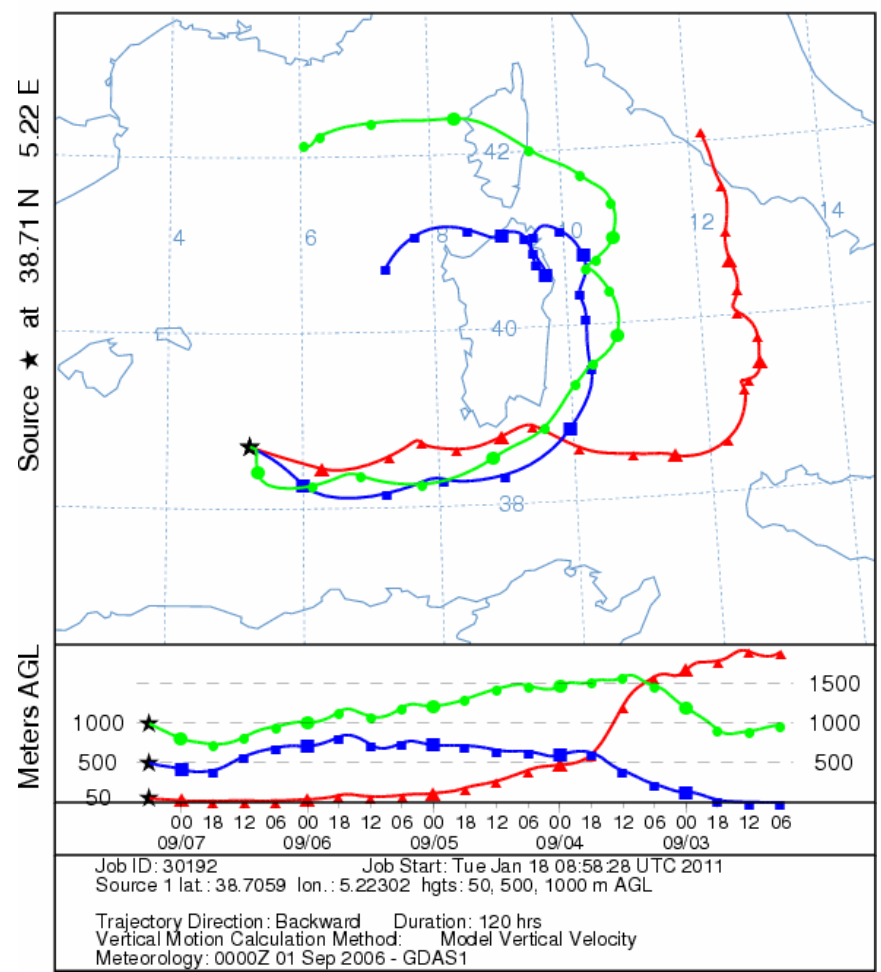

NOAA HYSPLIT MODEL Backward trajectories ending at 0600 UTC 08 Jun 06 GDAS Meteorological Data

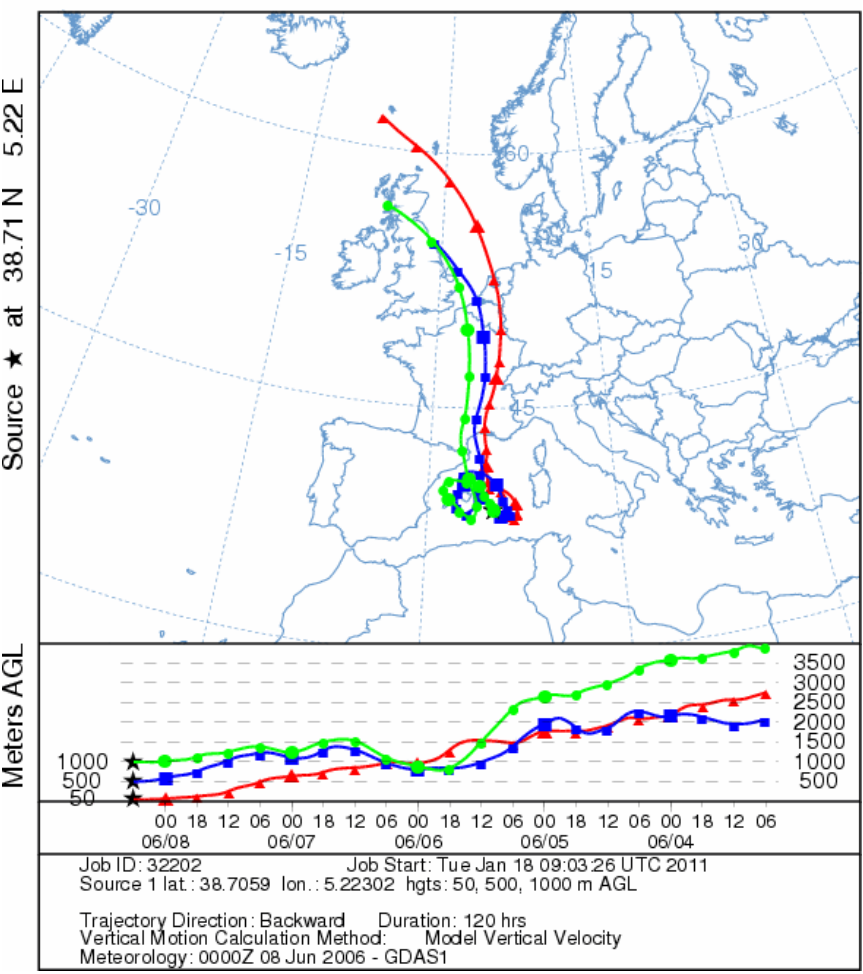

Fig. 9. 5-day back trajectories arriving at Costa Fortuna (track Tunis-Palma de Mallorca) for two typical "High" ozone cases in conditions of: regional summer anticyclone (breeze induced) (left) and synoptic anticyclone (right). Bottom panel: vertical cross sections of the trajectories. Tick marks are placed every $6 \mathrm{~h}$.

These trajectory calculations showed that high ozone levels are associated with air masses originating from the sector north to east-southeast (Central and South Europe) and their shape typically reflect the anticyclonic circulation around a pressure centre situated over the Mediterranean Sea. The back trajectories indicate that the air masses are brought down over Costa Fortuna from altitudes about 1000 to $3500 \mathrm{~m}$ due to the widespread subsidence in an anticyclone located over the Mediterranean and Central Europe. This behaviour was found in 7 out of the 8 cases of high ozone levels.

The trajectories calculated for the 9 cases of low ozone levels show a more complex behaviour; in most cases they are associated with westerly or north-westerly flow.

It should be mentioned that there are relevant uncertainties in the calculated back trajectories caused by errors in the input data, model assumptions and resolution. Stohl (1998) estimates the accuracy of computed trajectories with position errors of up to $20 \%$ of the travel distance. However, the results for the "High" and "Low" ozone episodes show substantial differences and provide evidence for the influence of the large scale flow on the measured ozone concentrations in this part of the Mediterranean Sea.

\subsection{Relationship between black carbon and ozone}

Black Carbon is emitted from combustion processes together with the precursors of ozone: $\mathrm{NO}_{\mathrm{x}}$, VOCs and carbon monoxide. Close to these sources the fast reaction between $\mathrm{NO}$ and ozone will reduce ozone concentrations and thus ozone is expected to show a negative correlation with BC. Moving away from the sources, atmospheric photochemistry will generate ozone from the precursors and thus ozone will tend to become positively correlated to $\mathrm{BC}$. The average atmospheric lifetime of $\mathrm{BC}$ is estimated to be between 5 and 8 days (Cooke, 2002), i.e somewhat shorter than the characteristic atmospheric lifetime of ozone. A calculation of the correlation coefficient for BC vs. ozone for each leg of the cruise gives a qualitative indication of to which extent the ozone concentrations in the air masses encountered are influenced by nearby emissions from combustion sources. Table 3 shows the calculated correlation coefficients: The first row gives the average of the correlation coefficients, calculated for each single journey. The long open sea track between Tunis and La Palma shows a significantly positive mean correlation coefficient and thus ozone concentrations in this area seem to be the least influenced by local emissions 
Table 3. Mean values and 90\% confidence intervals (assuming normal distribution) for the correlation coefficients (Pearson's correlation) for BC vs. ozone for each leg of the cruise for the period June, July and August in 2006 and 2007. In the first row, correlation coefficients have been calculated for each journey and then averaged. In the last row, the correlation coefficients for the aggregated data are shown

\begin{tabular}{lrrrrrrr}
\hline & $\begin{array}{r}\text { Savona- } \\
\text { Naples }\end{array}$ & $\begin{array}{r}\text { Naples- } \\
\text { Palermo }\end{array}$ & $\begin{array}{r}\text { Palermo- } \\
\text { Tunis }\end{array}$ & $\begin{array}{r}\text { Tunis- } \\
\text { Palma de Mallorca }\end{array}$ & $\begin{array}{r}\text { Palma de Mallorca- } \\
\text { Barcelona }\end{array}$ & $\begin{array}{r}\text { Barcelona- } \\
\text { Marseille }\end{array}$ & $\begin{array}{r}\text { Marseille- } \\
\text { Savona }\end{array}$ \\
\hline $\begin{array}{l}\text { Mean of } r \text { 's } \\
\text { for single cruises }\end{array}$ & -0.16 & 0.10 & -0.11 & 0.26 & -0.32 & -0.42 \\
\hline $\begin{array}{l}90 \% \text { confidence } \\
\text { interval for mean }\end{array}$ & $-0.29-$ & $-0.05-$ & $-0.26-$ & $0.14-$ & -0.25 \\
\hline$r$ for aggregated & -0.04 & 0.26 & -0.05 & 0.38 & $-0.45-$ & $-0.55-$ & $-0.39-$ \\
summer measurements & 0.04 & 0.41 & 0.20 & 0.47 & 0.05 & 0.03 & -0.19 \\
\hline
\end{tabular}

of NO. Also along the leg Naples-Palermo a positive, but weaker, correlation between $\mathrm{BC}$ and ozone was seen. The strongest negative correlations are found for the legs Palma de Mallorca-Barcelona and Barcelona-Marseille. These legs also showed the lowest mean ozone concentrations (Table 1). Both of these observations are consistent with a negative influence of local $\mathrm{NO}$ emissions on ozone concentrations.

The last row of Table 3 shows the correlation coefficients for the aggregated summer data; in this case all values are positive, although in some cases close to zero. The legs between Naples-Palermo, Tunis-Palma de Mallorca and, to a minor extent, Palermo-Tunis show the strongest positive correlations between $\mathrm{BC}$ and ozone. This gives evidence that these areas are mostly influenced by photochemically 'aged' air masses where the processing of ozone precursors has taken place for a relatively long time period.

The general picture that emerges is that looking at individual journeys, an increase in BC values is mostly associated with inputs from nearby local combustion sources that tend to reduce ozone concentrations because of the reaction of NO with ozone (this will be particularly important at nighttime, where there is no photochemical formation of ozone). However, looking at the aggregated data and thus comparing different days with different meteorological situations, $\mathrm{BC}$ tends to become mainly a tracer of polluted, ozone rich air masses and thus BC is positively correlated with ozone. Transects with long extensions are more likely to be influences by different air masses during a single journey than shorter transects; this may explain why the long transect Savona-Naples shows a less negative correlation factor for single journeys than the short transects Palma de MallorcaBarcelona and Barcelona-Marseille in spite of the large NOemissions from the Rome area.

Scatter plots of ozone vs. BC provided further insight into their relationship, as illustrated in Fig. 10 for the cases of Tunis-Palma and Barcelona-Marseille. For relatively low BC concentrations (typically below $\sim 500 \mathrm{ng} \mathrm{m}^{-3}$ ), a clear positive relationship between ozone and $\mathrm{BC}$ was found in all cases. For higher BC concentrations, there is a difference between the open sea leg Tunis-Palma and the legs where the route of the ship comes close to large urban areas on the coast, in this case illustrated by Barcelona-Marseille. In the first case, the positive correlation between ozone and $\mathrm{BC}$ is found throughout the whole range of $\mathrm{BC}$ concentrations while in the second case, the relationship tends to become more neutral or even negative for the higher $\mathrm{BC}$ concentrations. This is also likely to be explained by the influence of local combustion sources that cause elevated BC concentrations and reduced ozone levels on the route along the coast.

\subsection{Trajectory analysis of two ozone "hot spots"}

The maps of seasonally averaged ozone concentrations (Fig. 5) show some areas with particularly high concentrations of ozone. One of these is found close to the Marseilles area. A larger "hot spot" is found along the first part of the track between Savona and Naples, approximately down to the island of Corse, in the spring and summer months. Another area with high ozone concentrations is found along the transect Naples-Palermo. The occurrence of high ozone concentrations in these areas is also reflected in Table 1, where they show the highest $90 \%$ percentile values. In order to understand the origin of the air masses bringing high ozone concentrations to the latter two areas, back trajectories have been calculated for episodes where ozone levels above $60 \mathrm{ppbv}$ have been measured, using the Hysplit website as previously described.

During the periods from April to August 2006 and 2007, ozone measurements along the leg Savona-Naples are available for 42 cruises, out of which 21 show values above 60 ppbv for at least one hour in the part of the cruise indicated in red in Fig. 5. For the track Naples-Palermo ozone measurements are available for 41 cruises during this period and 14 of them show values above $60 \mathrm{ppbv}$ for at least one hour. All of these high levels were measured in the early evening, i.e. they represent ozone levels built up during the day. 
Tunis-Palma de Mallorca
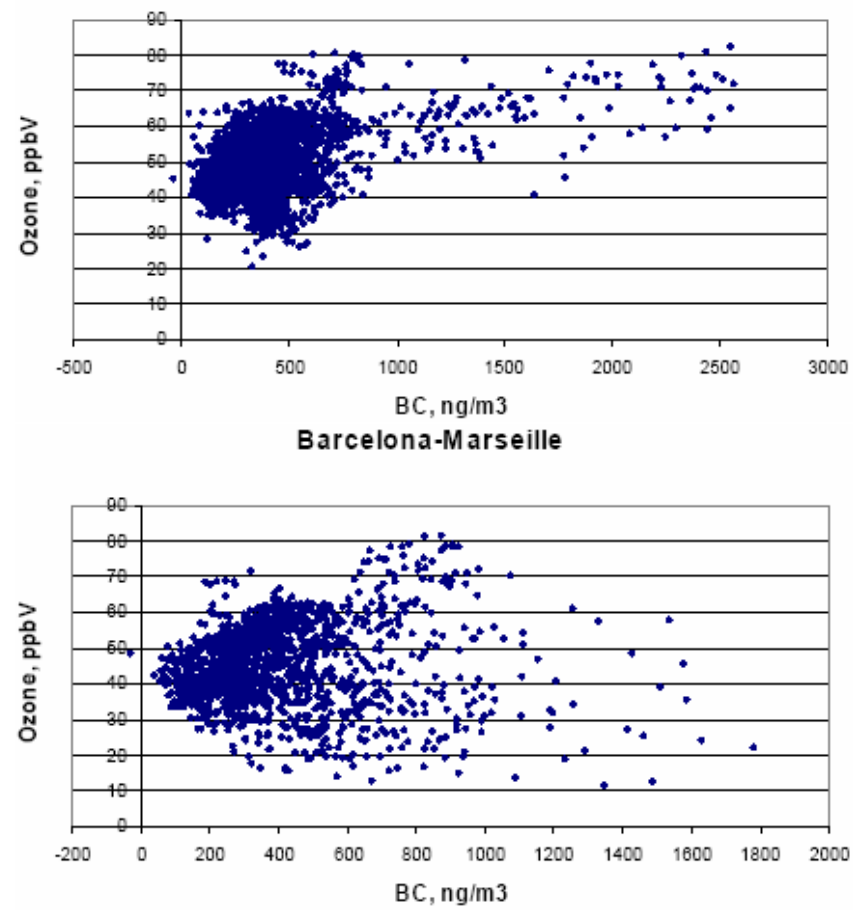

Fig. 10. Scatter plot of $B C$ vs. ozone for all measurements performed during the summer periods (June, July, August) of the years 2006 and 2007 along the legs Tunis-Palma de Mallorca (upper) and Barcelona-Marseille.

The back trajectories were classified according to the origin of the trajectory reaching the ship (50 m altitude) and the result is shown in Table 4, indicating the likely main source area of the ozone precursors. As can be seen, the main cause of high ozone levels in the Gulf of Genoa is found to be outflow of polluted air from the Po Valley (with contributions also from the Genoa area), the second main source appears to be the Marseille area. Along the track Naples-Palermo the Naples and the Rome areas seem to be the main precursor source areas.

Subsidence of air masses along the trajectories was observed, but the tendency was less pronounced than what was found for the leg Tunis-Palma de Mallorca.

As seen in Table 4, for several cases of high ozone levels the source area of the precursors is not evident from the trajectories and in most of these cases the trajectories indicate that the air masses have remained over the sea for the period of the analysis.

Ship emissions are gaining increasing importance as sources of both $\mathrm{NO}_{\mathrm{x}}$ and VOCs, and they might be one of the explanations for high ozone concentrations in air with trajectories of marine origin. However, the present study does not allow drawing conclusions about this impact. The recent modelling study by Marmer et al. (2009) finds that the
Table 4. Likely main source areas of ozone precursors for high ozone episodes observed in the Gulf of Genoa (21 episodes) and along the track Naples-Palermo (14 episodes) during April-August 2006 and 2007, according to the analysis of back trajectories (see text).

\begin{tabular}{lrrrrr}
\hline & $\begin{array}{r}\text { Marseille/ } \\
\text { South France } \\
\text { Gulf of Genoa }\end{array}$ & $\begin{array}{r}\text { Po } \\
\text { Valley } \\
24 \%\end{array}$ & Rome & Naples & $\begin{array}{r}\text { Sea/ } \\
\text { other } \\
9 \%\end{array}$ \\
\hline Naples-Palermo & $21 \% *$ & $0 \%$ & $29 \%$ & $29 \%$ & $21 \%$ \\
\hline
\end{tabular}

* Trajectories from Marseilles/South France have passed over the islands of Corse or Sardegna.

average impact of ship emissions on ozone along the route of Costa Fortuna in the Western Mediterranean is relatively small (a few ppbv).

\section{Conclusions}

These ship borne measurements have the advantage of providing regular observations from an area with a relatively large geographical extension. The disadvantage, when compared to a measurement station at a fixed site such as an island, is a lower measurement frequency at each location. The choice of performing measurements along a cruise track seems to be justified by the fact that seasonally averaged concentrations of ozone over the sea show a relatively large geographical variation (Fig. 5) which measurements at one or a few fixed observational sites might not have revealed.

The measurements show that high ozone levels over the open sea along the transect Tunis-Palma de Mallorca are mainly found in situations with an anticyclonic circulation over the Western Mediterranean. During summer, it appears that a well developed sea breeze regime induces an anticyclonic circulation over the whole region with subsidence over the sea. This finding is consistent with a number of comprehensive studies for the Western Mediterranean Basin performed by Millan et al. (1992, 1996, 1997, 2000, 2002, 2005). This regional, thermal type of anticyclone can be easily embedded into a synoptic scale high pressure system and thus intensify the general subsidence. At surface level the breeze regime is then manifested as a ridge of high pressure over the sea.

High ozone concentrations in this part of the Mediterranean were most often found in air masses brought down from aloft; thus the subsidence in this "regional summer anticyclone" appears to be a main reason for the high ozone levels.

The origin of air masses causing high ozone concentrations in the transect along the coast from the Gulf of Genoa down to the latitude of the island of Corse was studied by back-trajectory calculations. A similar analysis was made 
for the transect Naples-Palermo. High ozone concentrations along the Northwestern transect were found to be most often associated with outflow from the Po Valley and the Genoa area and, to a minor extent, trajectories from the Marseille area. For the Naples-Palermo transect Rome and Naples were found to be the most important source regions of ozone precursors. The backtrajectory analysis as well as the analysis of the relationship between ozone and $\mathrm{BC}$ indicate that the leg Naples-Palermo is more influenced by photochemically "aged" air masses than the leg Savona-Naples.

It has not been possible to apply a mesoscale model in the analysis of the observations presented here. As discussed in the introduction, several modeling studies of ozone formation in the Western Mediterranean basin have been published, most recently a comprehensive study of the Northwestern Mediterranean basin by Jiménez et al. (2006). Generally these studies agree on emphasizing the importance of recirculation systems, in agreement with the conclusions of the present study. These results give evidence that episodes with high ozone levels are mainly caused by local photochemical production of ozone.

Climate models predict that Mediterranean summers will be increasingly characterized by warm, dry weather with calm winds (IPCC, 2007). Thus it seems that the conditions that favour high ozone levels over the sea and along the coasts are likely to become more frequent in the coming years and the conditions that favour the build-up of ozone will presumably also promote the build-up of other secondary air pollutants, e.g. particles. Long term monitoring is needed to establish the actual trends in air pollution over the Mediterranean Sea; platforms on ships like the one reported in the present paper appear to offer an interesting possibility of providing such data.

Acknowledgements. We thank Sebastiao Martins Dos Santos, Paolo Cavalli and Alessandro Dell' Acqua for technical support to these measurements.

Edited by: T. Karl

\section{References}

Ancellet, G. and Ravetta, F.: Analysis and validation of ozone variability observed by lidar during the ESCOMPTE-2001 campaign, Atmos. Res., 74, 435-459, 2005

Anderson, B. E., Gregory, G. L., Barrick, D. W., Collins Jr., J. E., Sachse, G. W., Bagwell, D., Shipham, M. C., Bradshaw, J. D., and Sandholm, S. T.: The impact of US continental outflow on ozone and aerosol distributions over the western Atlantic, J. Geophys. Res., 98, 23477-23489, 1993

BADC (British Atmospheric Data Centre), available at: http://badc. nerc.ac.uk/community/trajectory/, 2007.

Beck, J. P., Kryzanowski, M., and Koffi, B.: Tropospheric Ozone in the European Union. "The Consolidated Report" by the European Topic Centre Air Quality, Bilthoven, European Commission, Office for Official Publication, 1999.
Bolle, H.-J.: Mediterranean Climate - Variability and Trends. Springer Verlag, Berlin, Heidelberg, New York, 2003.

Bouchlaghem, K., Nsom, B., and Lattrache, N.: Air quality variation under sea breeze conditions in Tunisian coasts, European Journal of Scientific Research, 23(4), 518-527, 2008.

Cooke, W. F., Ramaswamy, V., and Kasibhatla, P.: A general circulation model study of the global carbonaceous aerosol distribution, J. Geophys. Res., 107, D16, 4279, 10.1029/2001JD001274, 2002

EEA, Larssen, S.: Air pollution in Europe 1990-2000, Topic report 4/2003, 2004.

EMEP: EMEP/CCC-Report 1/95, available at: http://tarantula.nilu. no/projects/ccc/manual/index.html, 1996.

EMEP/CCC-Report 1/2005, Solberg, S., and Lindskog, A. (Eds.): The development of European surface ozone. Implications for a revised abatement policy, A contribution from the EU research project NEPAP, 2005.

EMEP 2009: available at: http://tarantula.nilu.no/projects/ccc/ emepdata.html, 2009.

Fishman, J., Creilson, J. K., Wozniak, A. E., and Crutzen, P. J.: Interannual variability of stratospheric and tropospheric ozone determined from satellite measurements, J. Geophys. Res. ,110, D20306, doi:10.1029/2005JD005868, 2005.

Gangoiti, G., Millan, M. M., Salvador, R., and Mantilla, E.: Long range transport and re-circulation of pollutants in the Western Mediterranean during the RECAPMA Project, Atmos. Environ., 35, 6267-62761, 2001.

Georgiadis, T., Giovanelli, G., and Fortezza, F.: Vertical layering of photochemical ozone during land-sea breeze transport, Nuovo Cimento, 17, 371-375, 1994.

HYSPLIT: available at: http://www.arl.noaa.gov/ready/open/ hysplit4.html, 2007.

IPCC: Climate Change, The Physical Science Basis, in: Intergovernmental Panel on Climate Change, edited by: Solomon S., Qin, D., Manning, M., Marquis, M., Averyt, K., Tignor, M. M. B., Miller Jr., H. L., and Chen, Z., Cambridge University Press, Cambridge, UK, 2007.

Jiménez, P., Lelieveld, J., and Baldasano, J. M.: Multiscale modeling of air pollutants dynamics in the northwestern Mediterranean basin during a typical summertime episode, J. Geophys. Res., 111, D18306, doi:10.1029/2005JD006516, 2006.

Johnson, J. E., Sundet, J. K., and Tarrason, L.: Model calculations of present and future levels of ozone and ozone precursors with a global and regional model, Atmos. Environ., 35, 525-537, 2001.

Kalabokas, P. D. and Repapis, C. C.: A climatological study of rural surface ozone in central Greece, Atmos. Chem. Phys., 4, 11391147, doi:10.5194/acp-4-1139-2004, 2004.

Kalabokas, P. D., Volz-Thomas, A., Brioude, J., Thouret, V., Cammas, J.-P., and Repapis, C. C.: Vertical ozone measurements in the troposphere over the Eastern Mediterranean and comparison with Central Europe, Atmos. Chem. Phys., 7, 3783-3790, doi:10.5194/acp-7-3783-2007, 2007.

Kalabokas, P. D., Mihalopoulos, N., Ellul, R., Kleanthous, S., and Repapis, C. C.: An investigation of the meteorological and photochemical factors influencing the background rural and marine surface ozone levels in the Central and Eastern Mediterranean, Atmos. Environ., 42, 7894-7906, 2008.

Kalnay, E., Kanamitsu, M., Kistler, R., Collins, W., Deaven, D., Gandin, L., Iredell, M., Saha, S., White, G., Woolen, J., Zhu, 
Y., Chelliah, M., Ebisuzaki, W., Higgins, W., Janowiak, J., Mo, K. C., Ropelewski, C., Wang, J., Leetmaa, A., Reynolds, R., Jenne, R., and Joseph, D.: The NCEP/NCAR Reanalysis 40-year Project, B. Am. Meteor. Soc., 77, 437-471, 1996.

Kourtidis, K., Zerefos, C., Rapsomanikis, S., Simeonov, V., Balis, D., Perros, P. E., Thomson A. M., Witte, J., Calpini, B., Sharobiem, W. M., Papayannis, A., Mihalopoulos, N., and Drakou, R.: Regional levels of ozone in the troposphere over eastern Mediterranean, J. Geoph. Res., 107(D18), 8140, doi:10.1029/2000JD000140, 2002.

Kouvarakis, G., Vrekoussis, M., Mihalopoulos, N., Kourtidis, K., Rappenglueck, B., Gerasopoulos, E., and Zerefos, C.: Spatial and temporal variability of tropospheric ozone $\left(\mathrm{O}_{3}\right)$ in the boundary layer above the Aegean Sea (eastern Mediterranean), J. Geophys. Res., 107(D18), 8137, doi:10.1029/2000JD000081, 2002.

Lelieveld, J.: Air pollution and climate, in: The Physical Geography of the Mediterranean, edited by: Woodward, J. C., Oxford University Press, 599-614, 2009.

Lelieveld, J., Berresheim, H., Borrmann, S., Crutzen, P. J., Dentener, F. J., Fischer, H., Feichter, J., Flatau, P. J., Heland, J., Holzinger, R., Korrmann, R., Lawrence, M. G., Levin, Z., Markowicz, K. M., Mihalopoulos, N., Minikin, A., Ramanathan, V., de Reus, M., Roelofs, G. J., Scheeren, H. A., Sciare, J., Schlager, H., Schultz, M., Siegmund, P., Steil, B., Stephanou, E. G., Stier, P., Traub, M., Warneke, C., Williams, J., and Ziereis, H.: Global air pollution crossroads over the Mediterranean, Science, 298, 794-799, 2002.

Lavander, K. A.: Marine exhausts emission quantification report, Final Report 99/EE/7044 prepared by Llyods register on behalf of the European Community, available at: http://ec.europa.eu/ environment/air/pdf/marine_exhausts.pdf, 2001.

Marmer, E., Dentener, F., Aardenne, J. V., Cavalli, F., Vignati, E., Velchev, K., Hjorth, J., Boersma, F., Vinken, G., Mihalopoulos, N., and Raes, F.: What can we learn about ship emission inventories from measurements of air pollutants over the Mediterranean Sea?, Atmos. Chem. Phys., 9, 6815-6831, doi:10.5194/acp-96815-2009, 2009.
Millan, M. M.: Ozone Dynamics In The Mediterranean Basin, A collection of scientific papers resulting from the MECAPIP, RECAPMA and SECAP Projects, European Commission and CEAM, La ImprentaComunication Grafica, Spain, 2002.

Millan, M. M., Salvador, R., Mantilla, E., and Kallos, G.: Photooxidant dynamics in the Western Mediterranean in summer: Results from European research projects, J. Geophys. Res., 102(D7), 8811-8823, 1997.

Millan, M. M., Mantilla, E., Salvador, R., Carratala, A., Sanz, M. J., Alonso, L., Gangoiti, G., and Navazo, M.: Ozone cycles in the western Mediterranean basin: interpretation of monitoring data in complex terrain, J. Appl. Meteorol. 4, 487-507, 2000.

Millan, M. M., Estrela, M. J., Sanz, M. J., Mantilla, E., Martin, M., Pastor, F., Salvador, R., Vallejo, R., Alonso, L., Gangoiti, G., Ilardia, J. L., Navazo, M., Albizuri, A., Artinano, B., Ciccioli, P., Kallos, G., Carvalho, R.A., Andres, D., Hoff, A., Werhahn, J., Seufert, G., and Versino, B.: Climatic Feedbacks and Desertification: The Mediterranean Model, J. Climate, 18, 684-701, 2005.

Nolle, M., Ellul, R., Heinrich, G., and Guesten, H.: A long-term study of background ozone concentrations in the central Mediterranean - diurnal and seasonal variations on the island of Gozo, Atmos. Environ., 36, 1391-1402, 2002.

Paoletti, E.: Impact of ozone on Mediterranean forests: A Review, Environ. Pollut., 144, 463-474, 2006.

Sokolik, I. N. and Toon, O. B... Incorporation of mineralogical composition into models of the radiative properties of mineral aerosol from UV to IR wavelengths, J. Geophys. Res., 104(D8), 94239444, 1999.

Stohl, A.: Computation, accuracy and applications of trajectories a review and bibliography, Atmos. Environ., 32, 947-996, 1998.

Ziomas, I. C.: The Mediterranean campaign of photochemical tracers-transport and chemical evolution (MEDCAPHOTTRACE): an outline, Atmos. Environ. 32, 2045-2053, 1998. 